\title{
EU ACCESSION EXPERIENCE AND PERSPECTIVES: THE CASE OF SLOVAKIA AND BOSNIA AND HERZEGOVINA*
}

\author{
Denisa Čiderová ${ }^{1}$ \\ Dubravka Kovačević
}

DOI: https://doi.org/10.31410/ERAZ.2019.245

\begin{abstract}
On 1 May 2019 the European Union marked 15 years since the gradual launch of its (South-) Eastern enlargement oriented on Central, Eastern and South-Eastern Europe as well as Mediterranean states. SCHIMMELFENNIG [5: 186-188] reminds us that "in early 1990, the EC [as a predecessor of the European Union encompassing twelve members - authors' remark] proposed to conclude association agreements without referring to, let alone promising, future membership. [...] Furthermore, the EC as a whole, and some of the reticent members in particular, used diverse delaying tactics to deflect the CEECs' [Central and Eastern European countries' - authors' remark] demands for full membership. On the one hand, they were offered alternative arrangements like French President Mitterrand's "European Confederation" or Prime Minister Balladur's "Stability Pact" for Europe as well as several ideas of "membership light" (that is, excluding the more cost-intensive Community policies). On the other hand, the urgency of other issues (such as the ratification of the Maastricht Treaty on European Union or accession negotiations with the EFTAns [additional European Free Trade Association aspirants for the EFTAn enlargement, having "reversed their initial decision to stay out of the common market" [6: 1867 - authors' remark]) has often provided a welcome opportunity to place the issue of Eastern enlargement at the end of the agenda".

Recently, "urgency of issues" could be linked to the post-crisis Roadmap for a More United, Stronger and more Democratic Union targeting the European Union's (EU) democratic, institutional and policy framework, or the pending withdrawal [alias Brexit] negotiations with the United Kingdom; yet, in February 2018 the European Commission "reaffirmed the firm, merit-based prospect of EU membership for the Western Balkans in its Communication A credible enlargement perspective for and enhanced EU engagement with the Western Balkans" [7: 1].
\end{abstract}

EU enlargement symbolises a multidimensional "Europeanisation" process due to the spectrum of (frequently mutually incompatible) interests (that are subject to modification in the course of time) of a number of actors, as BAUEROVA' [8: 204] puts it. In our article titled Visegrad meets Visegrad: the Visegrad Four and the Western Balkans Six (2015) we claimed that enlargement of the EU over the recent decade has not just expanded its territory or increased the headcount of its Single Market; by almost doubling the number of its members the Union faces multifaceted implications beyond any doubt. The CEECs, having been challenged by multiple transformation, assumed their rights just like

* This paper results from: scientific research conducted at the University of Economics in Bratislava in the framework of the KEGA project No. 002EU-4/2015 (Department of International Trade, Faculty of Commerce of the University of Economics in Bratislava), the VEGA research project No. 1/0654/16 (Institute of Economics and Management, University of Economics in Bratislava) and the VEGA research project No. 1/0812/19 (Institute of Economics and Management, University of Economics in Bratislava); chapters: [1] - [2] as well as an earlier chapter [3]; and is linked to the Ph.D. thesis titled Reflection of V4 Interests in the Context of V4 Presidencies in the Enlarging and Reforming European Union as a Prerequisite for Agenda-shaping in terms of the Netherlands - Slovakia - Malta (2016 - 2017) Presidency Troïka, successfully defended by PhD. Dubravka Kovačević in 2019 and supervised by Assoc. Prof. PhD. Denisa Čiderová, as well as the Master thesis [4] successfully defended by Ms. Beata Fejesová in 2013 and supervised by Assoc. Prof. PhD. Denisa Čiderová.

1 University of Economics in Bratislava, Faculty of Commerce, Dolnozemská cesta 1, 85235 Bratislava, Slovak Republic

2 University of Economics in Bratislava, Faculty of Commerce, Dolnozemská cesta 1, 85235 Bratislava, Slovak Republic 
obligations associated with EU membership upon completion of transitional periods intended to allow for as much a smooth integration process as possible; EU accession reinforced their prestige internationally to the extent of intensity of their participation. Bearing in mind that the process of Europeanisation (alias "EU-isation") could be EU-driven or domestically-driven [9: 8-9], our focus will be on the EU accession experience and perspectives in the case of the (among the Visegrad Group countries most integrated) Slovak Republic, and Bosnia and Herzegovina, respectively, in the light of the 2019 Communication on EU Enlargement Policy released on 29 May 2019.

Keywords: European Union enlargement, Europeanization, Western Balkans, Bosnia and Herzegovina, Slovak Republic.

\section{INTRODUCTION}

"The high hopes of a decade ago that all the rest of Southeastern Europe would be members of the European Union by 2014, on the very centenary of the Sarajevo assassination, have been set aside. The prospect of yet another difficult decade looms ahead, for regional members as well as aspirants. [...] None of the regional governments favour abandoning the wider EU association in favour of isolation or a new special relationship. Where the Europe these states have or hope to join as formally equal partners will itself proceed is, however, in question. The EU's own complex transition to an economic union has become a less settled prospect." LAMPE [10: 306 and 308].

A dozen of years ago, chapters of the monograph Evropske integracije-mostovi ka Balkanu (2006) titled "Politički aspekti evropskih integracija" and "Ekonomski aspekti evropskih integracija" gave insights into two opposing - yet mutually deeply and widely interconnected spheres of the EU's functioning. Their authors, namely M. VETRÁK [11] of the former and Z. MOGYOROSIOVÁ [12] of the latter, both explain the motives and origins for political as well as economic integration in the European context through different phases of their historical development and functioning: whilst M. VETRÁK analysed political aspects of European integration through the prism of EU legislation and the Union's institutions/bodies, Z. MOGYOROSIOVÁ described economic integration with its main forms in terms of the theoretical framework as well as applied to the Union's context, most notably through the customs union between the EU Member States (MSs), its internal market, and the economic and monetary union. In terms of the 1961 B. BALASSA's theory of economic integration ${ }^{3}$ intensifying bonds of economic nature from a free trade area upwards, it goes without saying that the Central European Free Trade Agreement played a significant role prior to accession of countries of Central and Eastern Europe to the European Union.

Following the Visegrad (alias the Visegrad Group) EU Presidencies, namely the 2009 Czech, and both the 2011 Hungarian and the 2011 Polish ones - as well as prior to the 2016 Slovak Presidency of the Council of the European Union - genesis of the 2004 Slovak EU accession 4 triggered contemplation represented by the following qualitative hypotheses: whether the former Yugoslav Republic of Macedonia, Montenegro, and Serbia will sign the European Union Accession Treaty in the course of the [2016] Slovak EU Presidency; and, whether European Un-

\footnotetext{
3 Represented (with gradually intensifying integration) by: a free trade area - a customs union - a common market - an economic union - complete economic integration [13, reprinted from The Theory of Economic Integration in 14: 180-1].

$4 \quad$ See [1: 438] 
ion accession negotiations with Albania, Bosnia and Herzegovina, and Kosovo under UNSCR 1244/1999 (in line with the ICJ Opinion on the Kosovo declaration of independence) will have already been initiated by December 2016, respectively. As a result of the 2015 mid-term testing of the respective qualitative hypotheses in a two-year interval after the initial 2013 assessment the team of authors came to the conclusions that: "Nonetheless, as in the initial 2013 assessment of the respective hypothesis ${ }^{5}$, we continue to reject it prior to the publication of the 2015 European Union Enlargement Package." [15: 107-108], and "Nonetheless, as in the initial 2013 assessment of the respective hypothesis ${ }^{6}$, we continue to reject it prior to the publication of the 2015 European Union Enlargement Package despite promisingly unfolding regional cooperation within the Western Balkans region and related engagement in further development of bilateral relations with other enlargement countries and neighbouring EU Member States. ... [T]he respective recommendations will be reflected by the European Commission in its 2015 Enlargement Package (Enlargement Strategy and Main Challenges 2015-16), too.” [16: 99], respectively.

Bearing in mind a sample of studies/reports carried out in the pre-/post-accession period ([7], [17] - [29]) and (resting on) a number of (our) earlier analyses ([1] - [3], [15] - [16], [30] - [49]) in the framework of the EU accession process, this follow-up paper aims to address the issue of the Slovak accession experience when reviewing status quo of the European integration process vis-à-vis Bosnia and Herzegovina in a "zoom-in"/"zoom-out" comparative perspective - with reference to recently released data - as well as challenges that lay ahead, taking into consideration the scope and limits of such analysis.?

\section{FLEXIBLE ENDOGENOUS AND EXOGENOUS EUROPEAN INTEGRATION}

The European Economic Area (EEA31) represents economic integration of extra-EU EFTA3 (Norway, Iceland, Liechtenstein) countries with 28 EU MSs, while the timing of the UK's withdrawal and related terms of UK cooperation with the post-Brexit EU27 continue to be subject to negotiation at the time this follow-up paper goes to press. Among the intra-EU Visegrad Group (Czechia, Hungary, Poland, and Slovakia) countries, Slovakia - having held its 2016 Presidency of the Council of the European Union - is fully integrated not just in the Schengen area, but even in the Euro area (alias EA19) ${ }^{8}$; the fact that all extra-EU EFTA4 (Norway, Iceland, Liechtenstein, Switzerland) countries are incorporated in the Schengen area, and certain degree of extra-EU euroisation relates to the so-called "European microstates" is at the heart of flexible endogenous and flexible exogenous integration of the European Union referred to in an earlier chapter by D. ČIDEROVÁ \& B. DIONIZI [3: 71 and 73]. With Slovakia having been selected as a benchmark in the 2008 World Bank study focused on Western Balkan Integration and the EU, we briefly look at the "Slovak success story" (as labelled by the OECD) in terms of EU accession experience before reflecting on the EU accession perspective of Bosnia and Herzegovina.

\footnotetext{
5 Whether the former Yugoslav Republic of Macedonia, Montenegro, and Serbia will sign the European Union Accession Treaty in the course of the [2016] Slovak EU Presidency

6 Whether European Union accession negotiations with Albania, Bosnia and Herzegovina, and Kosovo under UNSCR 1244/1999 (in line with the ICJ Opinion on the Kosovo declaration of independence) will have already been initiated by December 2016

7 Cf. methodological pluralism claimed by N. HYNEK [50: 173], and in [51: 466f].

8 The status of Bosnia and Herzegovina vis-à-vis the Euro currency in a comparative perspective was indicated in the earlier chapter [3: 73-74].
} 


\subsection{Eu Accession Experience: Focus on Slovakia}

In the earlier chapter [3: 75], relativity of impact of Slovakia was illustrated through its $1.06 \%$ share in EU28 population, its $0.79 \%$ share in EU28 GDP, and its representation in voting of the Council of the European Union by up to 1.99\% [2013 Eurostat est. cited in 22: 8]. And, Central European location of Slovakia, specified in Table 1 in Annex introducing basic facts about Slovakia and Bosnia and Herzegovina, in terms of "wider Europe" continues to be complemented by the fact that as much as $94 \%$ of the Slovak borderline stand for the Union's internal border [22: 28].

A decade after establishment of the Slovak Republic as one of two successors of the former Czechoslovakia in 1993 (Table 1 in Annex), Slovakia was involved in signing of the EU Accession Treaty on 16 April 2003. "Having graduated from this trying [EU-accession] preparatory process [on a journey from "policy takers" to "policy makers"], the countries in "the class of 2004" are now full-fledged members of the European Union, with equal rights to participate in the policy process shaping its future.", i.e. further development of the acquis, as formulated by ERIKSSON - KARLSSON - TARSCHYS [53: 3]. Within "the class of 2004", Slovakia was selected as a benchmark in the 2008 World Bank study titled Western Balkan Integration and the EU: An Agenda for Trade and Growth [18: 141] on the grounds that the Slovak Republic "has set many of its economic and social policies wisely and, as of the end of 2007, has been proceeding strongly toward its goals with a much stronger track record on macro-economic stability than many of its neighbouring countries. It is of course true that there is no unique path to growth and development, but the Slovak Republic seems to be as good a role model as any in the immediate neighbourhood of the Western Balkans.". The 2014 OECD Economic Survey of Slovakia presented the "Slovak success story" as follows: "The Slovak success story has benefited mainly the western part of the country. GDP per capita in Bratislava is the $6^{\text {th }}$ highest among 272 regions in the EU28 ..., although the country as a whole ranks only $20^{\text {th }}$ out of $28 E U$ countries." [54: 7]..$^{10}$

As a matter of fact, in the course of a dozen (2004 - 2015) of EU membership years, the GDP per capita (in PPS, EU28 = 100) of Slovakia fueled by the catching-up process rocketed from $56 \%$ in 2004 to $77 \%$ in 2015 [59]. ${ }^{11}$ Figure 1 in Annex reveals extensive inconsistency in the rate of GDP per capita in PPS in Slovakia \& Bosnia and Herzegovina when compared to the EA19 (EU28 being set as the standard at 100) in the 12-year time span $^{12}$ starting with the "Big Bang"

\section{Cf. [52].}

10 Cf. among 276 regions in the EU28 regional GDP per capita of the Bratislava region ranked: the 6th highest in 2014 [55], the 5th highest in 2015 [56], the 6th highest in 2016 [57]; and, following a change in methodology, regional GDP per capita of the Bratislava region was the 8th highest (2017) among 281 regions in the EU28 [58].

11 Cf. "As a result of relatively higher GDP growth rates, CEE10 countries achieved significant real convergence vis-à-vis the EA12 between 2004 and 2014. The CEE10 average GDP per capita level in purchasing power standards (PPS) increased from about $50 \%$ of the EA12 level in 2004 to above $58 \%$ in 2008. After having declined somewhat in 2009, it increased gradually to some $64 \%$ of the EA12 level in 2014. However, there was a considerable cross-country variation with the pace of convergence in general inversely related to initial income levels.... [R]elative GDP per capita levels in PPS increased by about 20 percentage points in Baltic countries, Poland, Romania and Slovakia", where CEE10 and EA12 stand for: ten Central and Eastern European countries that entered Union in 2004 and 2007; and the Euro area in 2004, respectively [27: 2 and 7].

12 In the case of Bosnia and Herzegovina data for 2004 are not available; 2017 updates (EU28 $=100$ ): 106 (EA19), 76 (SK), 31 (BA). With regard to available data for Kosovo (UNSCR 1244/1999) covered in the earlier chapter [3] cf. reference to "available indicators as well as anecdotal evidence" quoted in [60: 6]. In its 2014 report the European Commission introduced that "GDP per capita reached $€ 2,800$ in 2013, equal 
2004 EU15-to-EU25 enlargement (followed by the 2007 EU25-to-EU27 and the 2013 EU27-toEU28 ones). Although still being significantly below the EA19 average, SK GDP per capita in PPS demonstrates continuous upward or stable trend - even in the period of the global crisis during which the EA19 experiences minor contraction. Albeit incorporated into the EU-driven Stabilisation and Association Process, Bosnia and Herzegovina - still suffering from the hardship of the 1990s and not having settled yet - shows slow healing process when steadily moving towards $50 \%$ of the recent levels of GDP per capita in PPS registered by Slovakia (roughly an analogy to the SK standing vis-à-vis the EU average level in the advent of Slovak 2004 accession to the Union).

Functioning of multi-level governance in a broader context has been related not just exclusively to the European Union - it has also been dispersed to candidates and potential candidates for EU membership. M. A. VACHUDOVA [62: 65] claims that in the post-1989 era membership aspirants experienced both passive and active leverage (Table 2 in Annex) being exercised by the European Union (or its pre-Maastricht predecessor): passive leverage embodied in the mere existence of the EU with the Union's shared values, whereas its active counterpart encompassing tailor-made policy changes/adoption targeted at seizing the chance of becoming yet another "club" member. None of the mentioned leverages were caused by a deliberate action on behalf of the EU, moreover it is almost paradoxical that, for example, asymmetric interdependence, as part of active leverage and building upon its passive counterpart, has created self-imposed pressure among aspirants in their eagerness to join the European Union due to a somewhat lukewarm approach of some of the Union's Member States to its enlargement [62: 109-110]. In the case of EU accession states their compliance behaviour can be elucidated on the background of legitimacy ${ }^{13}$ and rationality in a matrix (Figure 2 in Annex) - further structured in self-explanatory Figure 3 in Annex - along these lines.

Within three decades between 1990 - 2019 the EU has not just expanded to eastern Bundesländer - now embracing all of 16 German Bundesländer - but it has continued to grow in a series of enlargement rounds from 12 to 28 members, too. Consequently, earlier members have had a stake in the enlargement-related decision-making in later stages, i.e. 2004 entrants vis-à-vis countries acceding in 2007 and 2013. Particularly the case of ex-Yugoslavia is one of gradual integration with the EU, spreading from Member State (Slovenia; Croatia) through candidate $^{14}$ country (Republic of North Macedonia; Montenegro; Serbia) to potential candidate status (Bosnia and Herzegovina; Kosovo/UNSCR 1244/1999); worth mentioning is that the number of negotiated acquis communautaire chapters transformed from 31 (e.g. in the case of the 2004 EU enlargement) into 35 (e.g. in the case of the 2013 EU enlargement). Both Kosovo

to $11 \%$ of the EU28 average" with observation that "a measure using purchasing power standards is not available for Kosovo" [61: 51]; alternatively, cf. its 2015 report [26: 43] with $€$ 2,935 (in 2013).

13 In the context of legitimacy of EU international relations, Ch. LORD [63] advices not to understand legitimacy as mere alternation of recognition, acceptance or support. He argues that EU citizens tend to approve procedures by which policies are made even when disliking them, especially bearing in mind the power that citizens have when shaping the ways of dealing with external issues in accordance to their own internal beliefs and values. Moreover, as taking place in the international arena, he warns that legitimacy is being contested by both, external and internal, spectators. In addition, the complexity of the EU and, therefore, its international legitimacy is often tempted by the fact that it can, but does not have to be assumed as legitimate by the outside audience. That being said, there is a clear implication of different dimensions of legitimacy that D. Beetham (1991, quoted by LORD in [63: 136]) distinguishes as: performance of the political system; popular identification with the system; and acquisition and exercise of power according to democratic values.

14 Since 2014 candidate country status related also to Albania 
(UNSCR 1244/1999) and Bosnia and Herzegovina being potential candidates for EU membership, emphasis will now be placed on the EU accession experience and perspectives as in the case of Slovakia and Bosnia and Herzegovina - on the background of: firstly, sovereignty in the Balkans; secondly, compliance behaviour among Balkan accession states; and thirdly, explaining the compliance behaviour in the Balkans.

\subsection{EU Accession Perspective: Focus on Bosnia and Herzegovina}

Claiming that delimitation of Europe as a so-called "pan-region" (or macro-region) represents a challenge particularly in the East, P. JUREK suggests addressing Eastern ${ }^{15}$ Europe and South-Eastern Europe ${ }^{16}$ adhered to by three civilisations ${ }^{17}$ as transitional regions intersecting the rim of the Eurasian as well as the Middle-Eastern pan-regions [64: 309-12 and 395]. ${ }^{18}$ Similarly to diverse application of the multifaceted term Balkan ${ }^{19}$, historical and/or geographic interpretation associated with the SEE region varies, too. ${ }^{20}$ Variability of internal dynamics specifically in the case of Serbia and Montenegro (2002-2006) and Kosovo (UNSCR 1244/1999) is outlined in Figure 4 in Annex; moreover, gradual progress towards EU membership in individual successors of ex-Yugoslavia (and ex-Czechoslovakia in a comparative perspective) is summarised in Table 3 in Annex.

In the preceding passage, a matrix of compliance behaviour on the background of legitimacy and rationality [62] with relevance to EU accession states was indicated. The aspect of asymmetry in the context of integration addressed by A. MORAVCSIK \& M. A. VACHUDOVA $(2003)^{21}$ is formulated by the latter as: "[T]remendous benefits combined with the enormous requirements for joining the EU create incentives for compliance that are different in kind and trigger different mechanisms of domestic change in candidates than in existing members of the $E U$." [62: 7]; the degree of compliance in terms of an interval stretching from non-compliance to substantial compliance of the Balkan accession states may be visualised on the background of Figure 5 in Annex. Having asked three pivotal questions in terms of costs of compliance and legitimacy: "Do the arguments based on cost-benefit calculations predominate the thinking of political actors in government?"; "What exactly is the balance in their consideration of gains and losses?"; "What is the degree of legitimacy accorded by domestic actors to EU demands?", NOUTCHEVA [70: 28-29] placed in Figure 6 in Annex (as application of Figure 2 in Annex) countries considered in Figure 4 in Annex.

When presenting the 2014 EU Enlargement package, former European Commissioner for Enlargement and Neighbourhood Policy Š. FÜLE [71] stated: "Five years ago, we set out to strengthen the credibility and the transformative power of enlargement policy. We put a particular emphasis on three pillars: rule of law in 2012, economic governance in 2013 and this year [2014], we're setting out new ideas to support public administration reform, and strengthening of democratic institutions. Today, this approach is bearing fruit. The process is credible and is bringing concrete results through reforms that gradually transform the countries con-

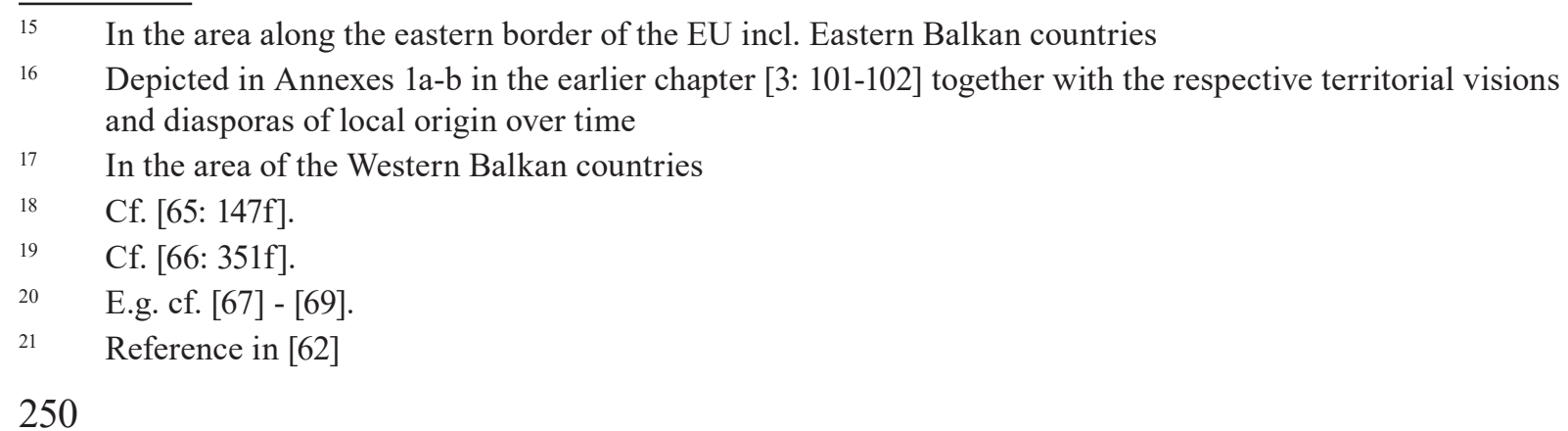


cerned, improving stability in our immediate neighbourhood. It also makes the countries better prepared for the EU entry and for the responsibilities of the membership.". Next, within the mandate of the new European Commission (since 1 November 2014) new High Representative for Foreign Affairs and Security Policy/Vice-President of the Commission F. MOGHERINI, and new Commissioner for European Neighbourhood Policy and Enlargement negotiations J. HAHN visited Sarajevo (vis-à-vis the case of Bosnia and Herzegovina documented in Table 4 in Annex) "to check if there was a level of engagement of commitment sufficient enough for us to want to engage in a process that could move Bosnia and Herzegovina closer to the European Union. The visit was extremely positive, we met with the presidency, we met with 12 political leaders in Parliaments, we met with civil society and we came to the conclusion that, yes, there can be a new start for EU and Bosnia and Herzegovina'." [72]. Because in the earlier chapter [3] we referred to the 2004 accession $^{22}$ of Slovakia to the European Union, and approximation ${ }^{23}$ of Kosovo (UNSCR 1244/1999) in the light of the EU acquis communautaire, with the adapted November 2015 "overarching medium-term strategy for EU enlargement policy" 24 we turned our attention in Table 5 in Annex to an articulate comparison of the state of play and (year-toyear) ${ }^{25}$ progress made by Bosnia and Herzegovina just like Kosovo (UNSCR 1244/1999) at the point of time of the medium-term strategy for EU enlargement policy.

As "In November 2015, the European Commission set out a medium-term strategy for EU enlargement policy" [(endorsed by the Council of the EU in December 2015) for the 2015 - 2019 mandate of the European Commission] is the opening statement of the European Commission in its follow-up 2016, 2018 \& 2019 editions of the Communication on EU Enlargement Policy ([7], [28] - [29]), this brings us to a summary and concluding remarks, which follow.

\section{CONCLUSION}

"[T]he Western Balkans region is completely surrounded by the EU member states. Any event taking place in any country of the region has direct or indirect impact on all others - members or non-members. The European project will thus not be accomplished without bringing the countries of the Western Balkans into the EU family. It is an Either-Or case. Either they will endorse our standards or we will have to deal with quasi- or limited democracies. On the other hand, we fully understand the worries of EU citizens to go ahead with enlargement. Nevertheless, we also remember their uncertainty and even fear when we were to enter the Union. In the end, they proved to be unfounded.

Due to many complex events of recent years, countries in the waiting room slowly see the EU losing its power to be a major influential actor. But as long as those countries keep their faith in the European project, we have to keep ours in them. So, allow me one more Either-Or to make the case for more dynamics in the enlargement process. Either we will feed our neighbourhood with a positive agenda or they will feed us with its own one, usu-

22 In terms of: [30: 15-19], [73] - [75].

23 In terms of: [76] - [77].

24 Still, the European Commission will "continue to adopt annual communications to take stock of progress, draw conclusions, make recommendations on thematic or country issues and propose adjustments to the overall strategy as necessary" [26: 13].

25 Mapping the status quo between October 2014 and September 2015, the overarching medium-term strategy for EU enlargement policy alias the 2015 EU Enlargement Strategy involves inter alia interaction with EU Member States and the governments of Bosnia and Herzegovina, and Kosovo (UNSCR 1244/1999), respectively. 
ally negative. Slovakia has invested a lot of efforts into the idea of a unified Europe with the Western Balkans' place in it. And I pledge to keep contributing to accomplishing this vision rather sooner than later.” M. LAJČÁK [78].

The EUROPEAN COMMISSION [26: 2] having stated in its medium-term strategy for EU enlargement policy released in November 2015 that "[w] hile there has been important progress by many countries in many areas over the past year, the challenges faced by these countries are such that none will be ready to join the EU during the mandate of the current Commission, which will expire towards the end of 2019", the COUNCIL OF THE EU [80: 2] then voiced the following December that "[i]n line with the renewed consensus on enlargement approved by the European Council on 14 and 15 December 2006, and the Council conclusions of 16 December 2014, the Council reiterates that enlargement remains a key policy of the European Union and an investment in the peace, democracy, prosperity, security and stability of our continent. In this context, the Council reiterates the EU's unequivocal commitment to the European perspective of the Western Balkans."

With the EU enlargement having been one of the priorities of the 2016 Slovak Presidency of the Council of the EU, according to the Minister of Foreign and European Affairs of the Slovak Republic M. LAJČÁK [78] recent progress achieved by Bosnia and Herzegovina ${ }^{26}$ provided enough arguments for putting its membership application on the September 2016 General Affairs Council agenda - in case of a decision tasking the European Commission to prepare its opinion on the application such preparation of the avis $^{27}$ would serve as a leverage ${ }^{28}$ rather than a reward. ${ }^{29}$

The COUNCIL OF THE EU [82] "reaffirms its commitment to enlargement, which remains a key policy of the European Union, in line with the renewed consensus on enlargement approved

$26 \quad$ Cf. "The Commission concluded that Bosnia and Herzegovina is back on the reform track and has started to address the outstanding priorities on its EU accession path." [79] and "The Council welcomes that Bosnia and Herzegovina is back on the reform path necessary to move forward in its EU integration process." [80: 16].

27 Cf. [81: 133].

28 Cf. [62: 65 and 108-109].

29 Cf. the statements vis-à-vis Kosovo (UNSCR 1244/1999) by the European Commission (“On 27 October 2015, the EU signed a Stabilisation and Association Agreement (SAA) with Kosovo. This is a milestone on Kosovo's path towards a European future. The SAA constitutes the first contractual relationship between the EU and Kosovo. It completes the map of SAAs with all Western Balkan countries. The SAA provides a comprehensive framework for closer political dialogue and economic relations between Kosovo and the EU, including opening EU markets to Kosovo products. Kosovo has demonstrated its commitment to the normalisation of relations with Serbia by reaching a number of key agreements" [25: 4]); the COUNCIL OF THE EU ("The Council takes good note of the signing in October [2015] of the Stabilisation and Association Agreement (SAA) with Kosovo. This EU-only agreement is the first comprehensive agreement between the EU and Kosovo. Its forthcoming conclusion, entry into force and implementation is without prejudice to Member States' positions on status. [...] The Council's intention to resume discussions on a framework agreement allowing Kosovo to participate in European Union programmes is without prejudice to Member States' positions on status" [80]) as well as the 2016 Slovak Presidency of the Council of the EU ("In Kosovo the Stabilization and Association Agreement entered into force. It represents a most tangible opportunity for Kosovo's further progress in its European perspective. Now the focus should be on its early implementation. [...] Let me underline that the normalization of relations with Belgrade simply has no alternative", LAJČÁK, 2016). À propos, the European Commission declared that "[t]here are no official relations with Kosovo, as Bosnia and Herzegovina does not recognise Kosovo as an independent state" [24: 29]) and "[t]here are no official relations with Bosnia and Herzegovina as the latter does not recognise Kosovo's independence" [25: 28]. 
by the European Council on 14 and 15 December 2006 and subsequent Council conclusions". In our timeline of ex-Yugoslavia and ex-Czechoslovakia in a comparative perspective (1990 2019) vis-à-vis EU accession (displayed in Table 3 in Annex) readers certainly noticed repeated "unconditional recommendation to open accession negotiations" by the EUROPEAN COMMISSION in the case of the former Yugoslav Republic of Macedonia (FYROM)/Republic of North Macedonia ${ }^{30}$ as a follow-up of such Commission's annual recommendations between 2009 - 2014; the COUNCIL OF THE EU applauded "the historic and unprecedented Prespa Agreement, and the Treaty on Good Neighbourly Relations with Bulgaria" in its conclusions on enlargement and stabilisation and association process (General Affairs Council meeting on 18 June 2019).

In a nutshell: "[r]eaffirming its conclusions of 26 June 2018, the Council takes good note of the Commission's recommendation to open accession negotiations [with both the Republic of North Macedonia as well as Albania] based on its positive evaluation of the progress made and of the fulfillment of the conditions identified by the Council. In light of the limited time available and the importance of the matter, the Council will revert to the issue with a view to reaching a clear and substantive decision as soon as possible and no later than October [2019]".

Under the SAP heading alike, having taken note of the EUROPEAN COMMISSION's Opin$i{ }^{31}$ on Bosnia and Herzegovina's application for membership of the European Union "[t]he Council will continue to examine this document thoroughly and revert to the matter later this year". In the case of Kosovo (UNSCR 1244/1999) the Council "reiterates the importance of the continued implementation of the Stabilisation and Association Agreement (SAA) with Kosovo. This EU-only agreement, which is without prejudice to Member States' positions on status, provides the contractual framework between the EU and Kosovo. [...] The Council deeply regrets the decisions by the government to impose unilateral tariff increases of up to 100\% on imports from Serbia and Bosnia and Herzegovina in November 2018, in violation of Central European Free Trade Agreement (CEFTA) obligations and of the spirit of the SAA, as well as the imposition of non-tariff barriers. The Council reiterates that these decisions undermine regional cooperation, including the Regional Economic Area, and must be immediately revoked." [82]. In the framework of accession negotiations (2025 accession outlook) with Montenegro (32 out of 35 negotiating chapters opened and 3 provisionally closed so far) as well as with Serbia (16 out of 35 negotiating chapters opened and 2 chapters provisionally closed so far) overall progress was made. ${ }^{32}$

$30 \quad$ "North Macedonia not only continued its ambitious reform agenda, but also reached a historic agreement with Greece resolving a 27 -year old name dispute. This, together with the bilateral agreement with Bulgaria, is an example of how to strengthen good neighbourly relations for the entire region, and testimony to the power of attraction of the European perspective." [29: 1-2].

31 "Bosnia and Herzegovina's accession would have a limited overall impact on European Union policies and would not affect the Union's capacity to maintain and deepen its own development. At the same time, identified functionality issues within Bosnia and Herzegovina, notably related to the internal decision-making process as well as uncertainty and overlaps between the country's various levels of government over a number of competences could negatively affect the decision-making process at EU level, particularly for matters requiring unanimity amongst EU Member States. Bosnia and Herzegovina should therefore engage in a process to address functionality issues in order to comply with EU membership requirements and take on its related obligations." [29: 20]. See also reference to public administration in Bosnia and Herzegovina as "a labyrinth of pre-war, wartime and post-war institutions, often exercising overlapping administrative authority" by GONZÁLEZ LÓPEZ [44: 17].

32 NB: For CEECs "nearly 15 years had passed from their independence until accession; Croatia, the last state to enter the Union in 2013, already needed 5 more years, i.e. a full decade from its application for membership to accession. [...] For the negotiation with Croatia, the acquis has been split into 35 chapters; 
F. SCHIMMELFENNIG \& U. SEDELMEIER [9: 7] defined "Europeanization" as "a process in which states adopt EU rules", and taking their view into account, J. WOELK [47: 29] comments that the transformation process of the CEECs has been characterised as "Europeanization" in order "to express the voluntary and endogenous character of adaptation to the acquis communautaire and its implementation through reforms". As a matter of fact, Europeanisation has been associated with the transformative power of the EU throughout the respective EC/EU enlargement rounds, and even beyond them as e.g. L. BACIU [83: 123] claims that "Croatia became the first of the seven countries from the Western Balkans to join the EU and it represents the best example of the EU's transformative power in the region". Yet, on account of five paradoxes (namely: "sovereignty paradox", "no-blueprint paradox", "good will paradox", "no-damage paradox", "mirror paradox") affecting the EU's transformative power in the Western Balkans according to WOELK [47: 35-36], the EU's transformative power in the Western Balkans has been, is being and will continue to be balanced on a scale with the "EU's geopolitical competitors"33. Thus, let us briefly recall what in his former position of the High Representative of the International Community and the Special Representative of the European Union in Bosnia and Herzegovina, M. LAJČÁK stressed: "We agreed that the Western Balkans is of all the closest to us. It is the target area of the European Union's further enlargement. We are bound to it by the geographic, historical, and linguistic proximity." and continued: "Slovakia still is a success story. It remains a motivation for the Western Balkan states, not an improbable role model for our geographically and mentally close co-members of the European Union." [84: 47-48 and 51]. Having attended the General Affairs Council meeting held in Luxembourg on 18 June 2019 in the position of the Minister of Foreign and European Affairs of the Slovak Republic, M. LAJČÁK as the OSCE Chairperson-in-Office visited Bosnia and Herzegovina on 20 June 2019. Acknowledging that "[i]t is a reality that differences exist, but parties should look to the future" and calling on national partners "to take steps towards creating a positive political climate and moving away from divisive rhetoric", he encouraged to explore all avenues to get the country back on track, including through adoption of key reforms: "[T]o make progress, political commitment, coherent and comprehensive strategies and uncompromised long term dedication are key.” [85].

\section{REFERENCES}

[1] Čiderová, D., Kovačević, D. (2015a) Slovakia and Croatia as „New” Member States of the EU: Experiences, pp. 429-445. In The European Union 10 years after its biggest enlargement: a ,new” EU member states' perspective, Poznań University of Economics Press, Poznań.

[2] Čiderová, D., Kovačević, D. (2015b) Slovakia and Croatia as „New” Member States of the EU: Perspectives, pp. 446-464. In The European Union 10 years after its biggest enlargement: a „new” EU member states’ perspective, Poznań University of Economics Press, Poznań.

more than 100,000 pages had to be translated. In 2010, Croatia delivered the Croatian language version (now considered an official EU version) to Bosnia and Herzegovina." [47: 29 and 33].

33 "[W]elcome progress achieved now calls for the Union's concrete and fast action. The EU has the opportunity, and a strong self-interest, to lock in long-term positive momentum across the region. The Union must live up to its commitments and give credit where credit is due. Failure to reward objective progress by moving to the next stage of the European path would damage the EU's credibility throughout the region and beyond. A tepid response to historic achievements and substantial reforms would undermine stability, seriously discourage much needed further reforms and affect work on sensitive bilateral issues like the Belgrade-Pristina dialogue. Strategically, it would only help the EU's geopolitical competitors to root themselves on Europe's doorstep." [29:3]. 
[3] Čiderová, D., Dionizi, B. (2015) EU Accession Experience and Perspectives: The Case of Slovakia and Kosovo (UNSCR 1244/1999), pp. 65-102. In Hoti, A., Kosír, I. (eds., 2015) European perspectives of the Western Balkans countries I, AAB College, Prishtina.

[4] Fejesová, B. (2013) Representing interests of V4 countries in terms of their Presidencies and the renewed consensus on enlargement - Western Balkans' focus, Master thesis supervised by Assoc. Prof. Dr. Denisa Čiderová, Bratislava.

[5] Schimmelfennig, F. (2003) The EU, NATO and the Integration of Europe. Rules and Rhetoric, Cambridge University Press, Cambridge.

[6] Schimmelfennig, F. (2016) Europe, pp. 178-201. In Börzel, T. A., Risse, Th. (eds., 2016) The Oxford Handbook of Comparative Regionalism, Oxford University Press, Oxford.

[7] European Commission (2018a) Communication from the Commission to the European Parliament, the Council, the European Economic and Social Committee and the Committee of the Regions. 2018 Communication on EU Enlargement Policy, Strasbourg, 17 April 2018, COM (2018) 450 final.

[8] Bauerová, H. (2014) Západní Balkán ante portam EU, pp. 189-206. In Bauerová, H., Hlaváčková, H., Cabada, L. (2014) Politika rozšiřování a země Západního Balkánu, Metropolitan University Prague Press, Praha.

[9] Schimmelfennig, F., Sedelmeier, U. (2005) Introduction: Conceptualizing the Europeanization of Central and Eastern Europe, pp. 1-28. In Schimmelfennig, F., Sedelmeier, U. (eds., 2005) The Europeanization of Central and Eastern Europe, Cornell University Press, Ithaca and London.

[10] Lampe, J. R. (2014) Balkans into Southeastern Europe, 1914-2014 - A Century of War and Transition ( $2^{\text {nd }}$ ed.), Palgrave Macmillan, Basingstoke.

[11] Vetrák, M. (2006) Politički aspekti evropskih integracija, pp. 17-32. In Sládek, K. (ed., 2006) Evropske integracije - mostovi ka Balkanu, Vydavatel'stvo/Izdavačka kuća/ Michala Vaška za /Centar za evropsku politiku/, Prešov.

[12] Mogyorosiová, Z. (2006) Ekonomski aspekti evropskih integracija, pp. 33-50. In Sládek, K. (ed., 2006) Evropske integracije - mostovi ka Balkanu, Vydavatel'stvo /Izdavačka kuća/ Michala Vaška za /Centar za evropsku politiku/, Prešov.

[13] Balassa, B. (1964) Teoria da integração económica. Estudos de economia moderna Clássica editora, Livraria Clássica Editora, Lisboa. (The Theory of Economic Integration, Richard D. Irwin, Inc., 1961).

[14] Nelsen, B. F., Stubb, A. (eds., 2003) The European Union - Readings on the Theory and Practice of European Integration ( $3^{\text {rd }}$ ed. - comprehensively revised and updated), Palgrave Macmillan, Basingstoke.

[15] Čiderová, D., Fejesová, B., Kovačević, D. (2015b) European Union enlargement to the Western Balkans applied to the Acapulco typology of agenda-setting: Focus on Montenegro, Serbia and FYROM revisited, pp. 101-109. Registered: Web of Science. In SGEM 2015. International multidisciplinary scientific conference on social sciences and arts. SGEM 2015: International multidisciplinary scientific conference on social sciences and arts, 26 August - 1 September, 2015, Albena, Bulgaria, STEF92 Technology, Sofia.

[16] Čiderová, D., Fejesová, B., Kovačević, D. (2015a) European Union enlargement to the Western Balkans applied to the Acapulco typology of agenda-setting: Focus on Albania, Bosnia and Herzegovina and Kosovo (under UNSCR 1244/1999) revisited, pp. 93-100. Registered: Web of Science. In SGEM 2015. International multidisciplinary scientific conference on social sciences and arts. SGEM 2015: International multidisciplinary scientific conference on social sciences and arts, 26 August - 1 September, 2015, Albena, Bulgaria. STEF92 Technology, Sofia. 
[17] Ústav slovenskej a svetovej ekonomiky SAV (2002) Ekonomické a sociálne súvislosti vstupu SR do EÚ - prínosy a riziká, Bratislava.

[18] Kathuria, S. (ed., 2008) Western Balkan Integration and the EU: An Agenda for Trade and Growth, The International Bank for Reconstruction and Development / The World Bank, Washington, D.C.

[19] European Commission (2009a) Five years of an enlarged EU - Economic achievements and challenges. European Economy, 1/2009.

[20] European Commission (2009b) The Western Balkans. European Economy, Occasional Papers, 46, May 2009.

[21] European Commission (2010) The pre-accession economies in the global crisis: from exogenous to endogenous growth? European Economy, Occasional Papers, 62, June 2010.

[22] Ministerstvo zahraničných vecí a európskych záležitostí Slovenskej republiky (2014) Hodnotiaca správa o 10 rokoch členstva $S R v E U ́$.

[23] Šikulová, I. et al. (2014) Slovenská ekonomika: desat' rokov členstva v Európskej únii. Vybrané témy a problémy, Ekonomický ústav Slovenskej akadémie vied, Bratislava.

[24] European Commission (2015a) Commission Staff Working Document. Bosnia and Herzegovina 2015 Report, Brussels, 10 November 2015, SWD (2015) 214 final accompanying EU Enlargement Strategy, Brussels, 10 November 2015, COM (2015) 611 final.

[25] European Commission (2015b) Commission Staff Working Document. Kosovo* 2015 Report, Brussels, 10 November 2015, SWD (2015) 215 final accompanying EU Enlargement Strategy, Brussels, 10 November 2015, COM (2015) 611 final.

[26] European Commission (2015c) Communication from the Commission to the European Parliament, the Council, the European Economic and Social Committee and the Committee of the Regions. EU Enlargement Strategy, Brussels, 10 November 2015, COM (2015) 611 final.

[27] European Commission (2015d) Economic Convergence of Central and Eastern European EU Member States over the Last Decade (2004-2014). European Economy, Discussion Paper, 001, July 2015.

[28] European Commission (2016) Communication from the Commission to the European Parliament, the Council, the European Economic and Social Committee and the Committee of the Regions. 2016 Communication on EU Enlargement Policy, Brussels, 9 November 2016, COM (2016) 715 final.

[29] European Commission (2019) Communication from the Commission to the European Parliament, the Council, the European Economic and Social Committee and the Committee of the Regions. 2019 Communication on EU Enlargement Policy, Brussels, 29 May 2019, COM (2019) 260 final.

[30] Báráňová-Čiderová, D., Svitana, R., Vetrák, M. (2006) Budúcnost' EÚ. Rozširovanie EÚ. Hranice EÚ, Vydavatel'stvo Michala Vaška, Prešov, pre Centrum pre európsku politiku, Bratislava.

[31] Sládek, K. (ed., 2006) Evropske integracije - mostovi ka Balkanu, Vydavatel'stvo /Izdavačka kuća/ Michala Vaška za /Centar za evropsku politiku/, Prešov.

[32] Kosír, I. et al. (2007) Zlepšovanie systémových predpokladov na efektívnejšiu realizáciu výhod členstva $S R$ v EÚ na podnikovej úrovni. Vedecká recenzovaná monografia č. 5, Vydavatel'stvo EKONÓM, Bratislava.

[33] Báráňová-Čiderová, D. (2007) Rozširenie EÚ na východ : prínosy a riziká rozširenia Európskej únie o krajiny strednej a východnej Európy pre EÚ, Vydavatel'stvo EKONÓM, Bratislava. 
[34] Baláž, P., Báráňová-Čiderová, D. (ed.), Kittová, Z. (ed.), Kosír, I., Liberčan, A., Mattoš, B., Silná, Z., Vetrák, M. (2008) Alternatívy vývoja európskej integrácie, Vydavatel'stvo EKONÓM, Bratislava.

[35] Kosír, I. (2010) Medzinárodná ekonomická integrácia. Od autarkie ku globálnej ekonomickej integrácii, FPVMV UMB, Banská Bystrica.

[36] Fodorová, V., Grančay, M., Szikorová, N., et al. (2012) Integrácia západného Balkánu a Turecka do Európskej únie: Kniha 1 - komplexný pohl'ad, Vydavatel'stvo EKONÓM, Bratislava.

[37] Grančay, M., Szikorová, N., et al. (2012) Integrácia západného Balkánu a Turecka do Európskej únie: Kniha 2 - individuálny aspekt, Vydavatel'stvo EKONÓM, Bratislava.

[38] Hoti, A., Kosír, I. (eds., 2015) European perspectives of the Western Balkans countries I, AAB College, Prishtina.

[39] Čiderová, D., Kovačević, D. (2015c) Visegrad meets Visegrad: The Visegrad Four and the Western Balkans Six. In European Scientific Journal, Special edition, Vol. 1, No. October. European Scientific Institute and University of the Azores, Azores.

[40] Čiderová, D., Kosír, I., Kovačević, D., Liberčan, A., Repášová, V. (2015) Alternatívy vývoja európskej integrácie. Čast' 2. 2. preprac. a dopln. vyd., Vydavatel'stvo EKONÓM, Bratislava.

[41] Kovačević, D., Čiderová, D. (2015) Reflection of V4 countries in the context of V4 presidencies in the enlarging and reforming European Union as a prerequisite for agenda-shaping in terms of the Netherlands - Slovakia - Malta (2016-2017) presidency Troïka, pp. 263-270. Registered: Web of Science. In SGEM 2015. International multidisciplinary scientific conference on social sciences and arts. SGEM 2015: International multidisciplinary scientific conference on social sciences and arts, 26 August - 1 September, 2015, Albena, Bulgaria, STEF92 Technology, Sofia.

[42] Zupančič, R., Pejič, N. (2018) The EU's Affair with Kosovo, pp. 33-63. In Zupančič, R., Pejič, N. (2018) Limits to the European Union's Normative Power in a Post-conflict Society, Springer.

[43] Grimaud, J. M. (2018) A Historical Perspective of Small States in the European Union, pp. 13-33. In: Grimaud, J. M. (2018) Small States and EU Governance. Palgrave Macmillan, Basingstoke.

[44] González López, J. (2018) Bosnia and Herzegovina: a Case Study for the Unfinished EU Agenda in the Western Balkans, ZEI Discussion Papers, C250.

[45] Stanišić, N., Makojević, N., Tubić Ćurčić, T. (2018) The EU Enlargement and Income Convergence: Central and Eastern European Countries vs. Western Balkan Countries. In Entrepreneurial Business and Economics Review, 3/2018, pp. 29-41.

[46] Kittová, Z., Steinhauser, D. (2018) The International Economic Position of Western Balkan Countries in Light of their European Integration Ambitions, pp. 51-68. In Journal of Competitiveness, Vol. 10, No. 3, 2018.

[47] Woelk, J. (2019) From Enlargement Perspective to "Waiting for Godot"? Has the EU Lost Its Transformative Power in the Balkans? pp. 27-47. In ANTONIOLLI, L. et al. (eds., 2019) Highs and Lows of European Integration, Springer.

[48] Smetana, M., Ludvík, J. (2019) Between war and peace: a dynamic reconceptualization of "frozen conflicts". In Asia Europe Journal, 2019, 17: 1-14.

[49] Perry, V. (2019) Frozen, stalled, stuck, or just muddling through: the post-Dayton frozen conflict in Bosnia and Herzegovina. In Asia Europe Journal, 2019, 17: 107-127.

[50] Kratochvíl, P., Drulák, P. (eds., 2009) Encyklopedie mezinárodních vztahů, Portál, Praha. 
[51] Eilstrup-Sangiovanni, M. (ed., 2006) Debates on European Integration - A Reader, Palgrave Macmillan, Basingstoke.

[52] Commission of the European Communities (2003) Communication from the Commission to the Council and the European Parliament. Wider Europe - Neighbourhood: A New Framework for Relations with our Eastern and Southern Neighbours. Brussels, 11 March 2003, COM (2003) 104 final.

[53] Eriksson, J., Karlsson, B. O., Tarschys, D. (eds., 2005) From Policy Takers to Policy Makers: Adapting EU Cohesion Policy to the Needs of the New Member States, Swedish Institute for European Policy Studies, Stockholm.

[54] OECD (2014) OECD Economic Surveys Slovak Republic - Overview, November 2014.

[55] Eurostat (2016) 2014 GDP per capita in 276 EU regions, eurostat newsrelease No. 39/2016, 26 February 2016.

[56] Eurostat (2017) 2015 GDP per capita in 276 EU regions, eurostat newsrelease No. 52/2017, 30 March 2017.

[57] Eurostat (2018) Regional GDP per capita ranged from $29 \%$ to $611 \%$ of the EU average in 2016, Eurostat news release No. 33/2018, 28 February 2018.

[58] Eurostat (2019b) Regional GDP per capita ranged from $31 \%$ to $626 \%$ of the EU average in 2017, Eurostat news release No. 34/2019, 26 February 2019.

[59] Eurostat (2019a) GDP per capita in PPS Index (tec00114).

[60] European Commission (2014b) EU Candidate \& Potential Candidate Countries' Economic Quarterly (CCEQ), 3/2014, ISSN 1830-6292.

[61] European Commission (2014e) Progress towards meeting the economic criteria for EU accession: the EU Commission's 2014 assessments. European Economy, Occasional Papers, 205, December 2014, ISSN 1725-3209.

[62] Vachudova, M. A. (2005) Europe Undivided. Democracy, Leverage, \& Integration After Communism, Oxford University Press, Oxford.

[63] Lord, Ch. (2011) Legitimate and Democratic? The EU's International Role, pp. 128-148. In: Hill, Ch., Smith, M. (2011) International Relations and the European Union (2 $\left.{ }^{\text {nd }} \mathrm{ed}.\right)$, Oxford University Press, Oxford.

[64] Jurek, P. (2011). Evropa, pp. 303-334. In: Cabada, L., Šanc, D., et al. (2011) Panregiony ve 21. století. Vývoj a perspektivy mezinárodních makroregionů, Aleš Čeněk, Plzeň.

[65] Ivanička, K. (2006) Globalistika - Poznávanie a riešenie problémov súčasného sveta, IURA EDITION, Bratislava.

[66] Ježová, M. (2011) Přechodové regiony, pp. 335-357. In: Cabada, L., Šanc, D., et al. (2011) Panregiony ve 21. století. Vývoj a perspektivy mezinárodních makroregionů, Aleš Čeněk, Plzeň.

[67] Girgle, P. (2009) Kosovo, Stručná historie států sv. 57 (2 $2^{\text {nd }}$ ed.), Libri, Praha.

[68] Pelikán, J., Havlíková, L., Chrobák, T., Rychlík, J., Tejchman, M., Vojtěchovský, O. (2004) Déjiny Srbska, Nakladatelství Lidové noviny, Praha.

[69] Hradečný, P., Hladký, L. (co-authorship of Monari, V., Š́stek, F., Burdová Hradečná, P., 2008) Dějiny Albánie, Nakladatelství Lidové noviny, Praha.

[70] Noutcheva, G. (2012) European Foreign Policy and the Challenges of Balkan Accession - Conditionality, Legitimacy and Compliance (UACES Contemporary European Studies), Routledge, Abingdon/Oxon and New York.

[71] European Commission (2014c) EU enlargement in 2014 and beyond: progress and challenges, Brussels, 8 October 2014, Press release IP/14/1100.

[72] EEAS (2014) Remarks by High Representative on the Foreign Affairs Council on 15 December 2014, Brussels, 15 December 2014, 141215_4_en. 
[73] European Commission Report on the results of the negotiations on the accession of Cyprus, Malta, Hungary, Poland, the Slovak Republic, Latvia, Estonia, Lithuania, the Czech Republic and Slovenia to the European Union.

[74] Figel', J., Adamiš, M. (2004) Slovensko na ceste do Európskej únie. Kapitoly a súvislosti ( $3^{\text {rd }}$ ed.), Úrad vlády Slovenskej republiky, Bratislava.

[75] Treaty concerning the accession of the Czech Republic, the Republic of Estonia, the Republic of Cyprus, the Republic of Latvia, the Republic of Lithuania, the Republic of Hungary, the Republic of Malta, the Republic of Poland, the Republic of Slovenia and the Slovak Republic to the European Union (incl. the Act concerning the conditions of accession of the Czech Republic, the Republic of Estonia, the Republic of Cyprus, the Republic of Latvia, the Republic of Lithuania, the Republic of Hungary, the Republic of Malta, the Republic of Poland, the Republic of Slovenia and the Slovak Republic; Annexes; Protocols; and the Final Act), Official Journal of the European Union, L 236, 23 September 2003; Official Journal of the European Union, C 227 E, 23 September 2003, http://eur-lex.europa. eu/LexUriServ/LexUriServ.do?uri=OJ:L:2003:236:0033:0049:EN:PDF.

[76] European Commission (2014a) Commission Staff Working Document. Kosovo* 2014 Progress Report, Brussels, 8 October 2014, SWD (2014) 306 final accompanying Enlargement Strategy and Main Challenges 2014-2015, Brussels, 8 October 2014, COM (2014) 700 final.

[77] European Commission (2014d) Key findings of the Progress Report on Kosovo, Brussels, 8 October 2014, MEMO/14/555.

[78] Lajčák, M. (2016) The Western Balkans and the EU: Cooperation and Integration, Inter-Parliamentary Conference on CFSP, Bratislava, 4 September 2016.

[79] European Commission (2015e) Key findings of the 2015 report on Bosnia and Herzegovina, Brussels, 10 November 2015, MEMO/15/6034.

[80] Council of the EU (2015) Council conclusions on Enlargement and Stabilisation and Association Process - Annex, General Affairs Council meeting, Brussels, 15 December 2015.

[81] Gateva, E. (2015) European Union Enlargement Conditionality, Palgrave Macmillan, Basingstoke.

[82] Council of the EU (2019) Council conclusions on enlargement and Stabilisation and association process, General Affairs Council meeting, Luxembourg, 18 June 2019.

[83] Baciu, L. (2016) The EU Western Balkans Enlargement: The role of the EU-OSCE political cooperation in the field of the Rule of Law in countries preparing for the EU accession. In International Journal on Rule of Law, Transitional Justice and Human Rights, 7/2016: 121-129.

[84] Lajčák, M. (2008) The Western Balkans: The Need for a New Vision and Strategy, New Challenges and New Approaches Conference Reviewing the Foreign Policy of the Slovak Republic in 2007 organised by the Research Center of the Slovak Foreign Policy Association and the Ministry of Foreign Affairs of the Slovak Republic, Bratislava, 17 April 2008.

[85] OSCE (2019) OSCE Chairperson Lajčák urges BiH political leaders to re-engage in dialogue and intensify efforts to advance the reform agenda. Sarajevo, 21 June 2019, press release available at: https://www.osce.org/chairmanship/423743.

[86] The World Almanac ${ }^{\circledR}$ and Book of Facts (2014), Infobase Learning, New York.

[87] The World Almanac ${ }^{\circledR}$ and Book of Facts (2015), Infobase Learning, New York.

[88] European Commission (2015f) Western Balkans and Turkey: enlargement process key to strengthened economic and political stability in the region, Brussels, 10 November 2015, Press release IP/15/5976.

[89] European Commission (2018b) Communication from the Commission to the European Parliament, the Council, the European Economic and Social Committee and the Commit- 
tee of the Regions. A credible enlargement perspective for and enhanced EU engagement with the Western Balkans, Strasbourg, 6 February 2018, COM (2018) 65 final.

[90] European Commission (2017) White Paper on the Future of Europe: Reflections and scenarios for the EU27 by 2025, Brussels, 1 March 2017, COM (2017) 2025.

[91] Inglis, K. (2010) Evolving Practice in EU Enlargement - with Case Studies in Agri-Food and Environment Law, Volume 4 of Studies in EU External Relations (series edited by Marc Maresceau, Ghent University), Martinus Nijhoff Publishers, Leiden and Boston.

[92] Šesták, M., Tejchman, M., Havlíková, L., Hladký, L., Pelikán, J. (1998) Dějiny jihoslovanských zemí, Nakladatelství Lidové noviny, Praha.

[93] Š́bl, D. et al. (2002) Vel’ká ekonomická encyklopédia - Výkladový slovník A-Ž, Sprint, Bratislava.

[94] Official portal of the European Union http://europa.eu.

[95] Council of the EU (2014) Council conclusions on Enlargement and Stabilisation and Association Process, General Affairs Council meeting, Brussels, 16 December 2014. 


\section{ANNEX}

Table 1: Slovakia \& Bosnia and Herzegovina in a comparative perspective: basic facts (based on [86: 796-7 and 833] - [87: 756 and 832-3])

\begin{tabular}{|c|c|c|}
\hline & Slovakia & Bosnia and Herzegovina \\
\hline Total area & $49,035 \mathrm{~km}^{2}$ & $51,197 \mathrm{~km}^{2}$ \\
\hline Land area & $48,105 \mathrm{~km}^{2}$ & $51,187 \mathrm{~km}^{2}$ \\
\hline Location & Central Europe & SE Europe \\
\hline Population & $5,492,677$ & $3,871,643$ \\
\hline Ethnic groups & $\begin{array}{l}\text { Slovak } 81 \% \text {; Hungarian 9\%; } \\
\text { Roma 2\%; } \\
\text { Ruthenian/Ukrainian }\end{array}$ & $\begin{array}{l}\text { Bosniak 48\%; } \\
\text { Serb 37\%; Croat 14\% }\end{array}$ \\
\hline Chief religions & $\begin{array}{l}\text { Roman Catholic 62\%; } \\
\text { Protestant } 8 \% \text {; } \\
\text { Greek Catholic 4\%; none 13\% }\end{array}$ & $\begin{array}{l}\text { Muslim 40\%; } \\
\text { Orthodox 31\%; } \\
\text { Roman Catholic 15\% }\end{array}$ \\
\hline Principal languages & $\begin{array}{l}\text { Slovak (official), } \\
\text { Hungarian, Roma, Ukrainian }\end{array}$ & $\begin{array}{l}\text { Bosnian, Croatian } \\
\text { (both official); } \\
\text { Serbian }\end{array}$ \\
\hline Establishment & 1993 & 1992 \\
\hline $\begin{array}{l}\text { Member of major international } \\
\text { organisations }\end{array}$ & $\begin{array}{l}\text { UN, EU (2004; Schengen 2007; } \\
\text { Euro area 2009), NATO (2004), } \\
\text { OECD (2019 OECD Ministerial } \\
\text { Council Meeting under the } \\
\text { Presidency of the Slovak Republic), } \\
\text { OSCE (Slovak } 2019 \text { OSCE } \\
\text { Chairmanship), WTO }\end{array}$ & UN, OSCE \\
\hline
\end{tabular}

Table 2: Comparative perception of the passive leverage and active leverage concept (based on the passive leverage and active leverage concept by VACHUDOVA

[62: 65 and 108-109])

\begin{tabular}{|c|c|c|}
\hline Passive leverage & versus & e leverage \\
\hline Benefits are shaped by: & \multirow{3}{*}{\begin{tabular}{l|l} 
Characteristics \\
of the pre-accession process:
\end{tabular}} & \multirow{3}{*}{$\begin{array}{l}\text { Requirements of } E U \\
\text { membership: }\end{array}$} \\
\hline $\begin{array}{l}\text { Costs of exclusion when neighbouring } \\
\text { states are joining; }\end{array}$ & & \\
\hline EU treatment of non-members & & \\
\hline Political benefits: & \multirow[t]{3}{*}{ Asymmetric interdependence } & \multirow[t]{3}{*}{ Copenhagen political criteria } \\
\hline Protection of EU rules; & & \\
\hline Voice in EU decision-making & & \\
\hline Economic benefits: & \multirow[t]{5}{*}{ Enforcement } & \multirow[t]{5}{*}{ Copenhagen economic criteria } \\
\hline Access to EU market; & & \\
\hline Transfers from EU budget; & & \\
\hline Increased investment + growth; & & \\
\hline Increased entrepreneurship + skills & & \\
\hline Additional benefit: & \multirow[t]{2}{*}{ Meritocracy } & \multirow[t]{2}{*}{ Acquis communautaire } \\
\hline $\begin{array}{l}\text { EU membership conditionality } \\
\text { as a catalyst for domestic reform }\end{array}$ & & \\
\hline
\end{tabular}




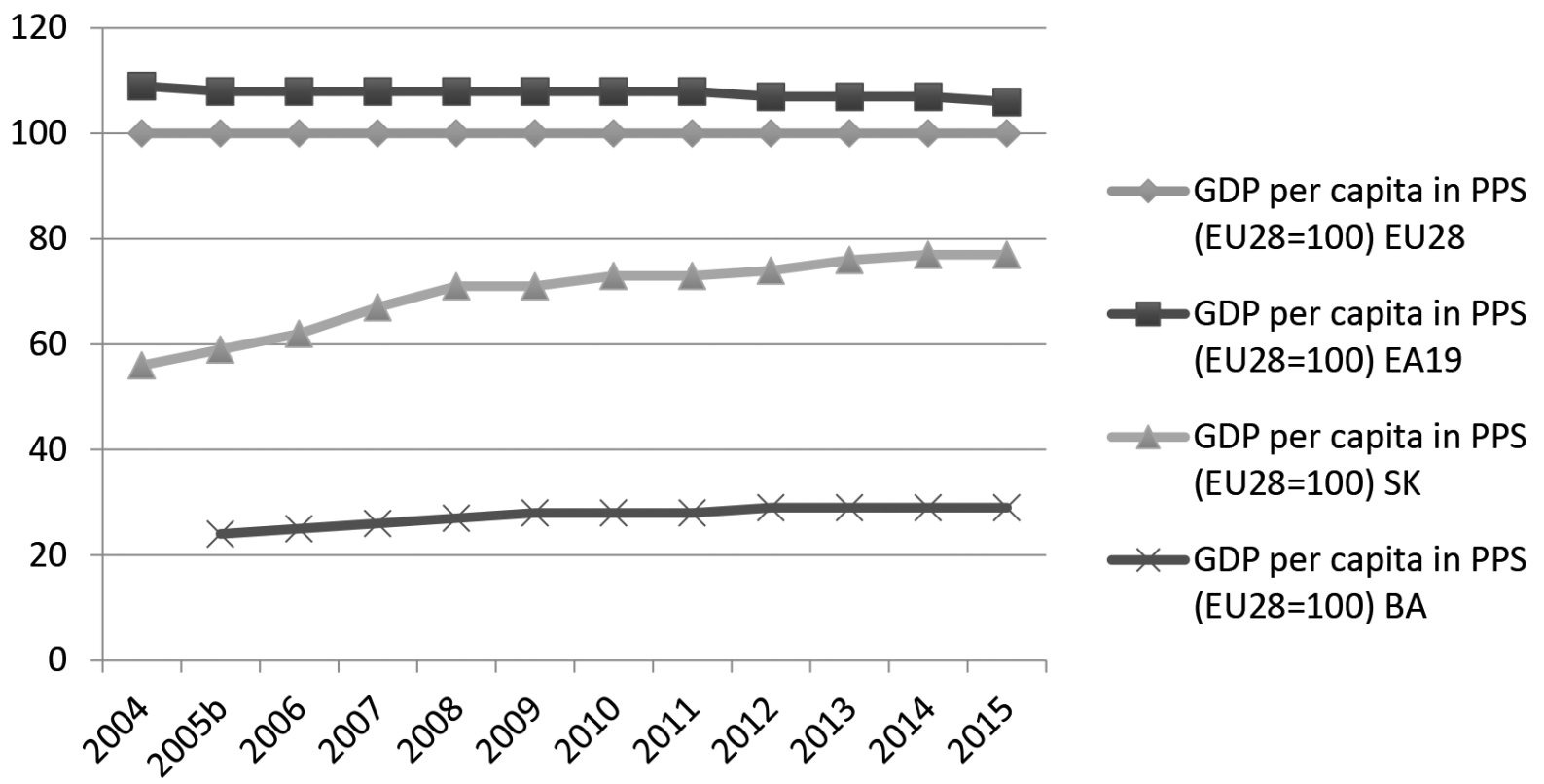

Legend: $\quad$ EU - European Union; EA - Euro area; SK - Slovakia; BA - Bosnia and Herzegovina; $\mathrm{b}$ - break in time series.

Figure 1: Slovakia \& Bosnia and Herzegovina in a comparative perspective: GDP (per capita in PPS; EUROSTAT [59])

\begin{tabular}{ll|c|c|}
\multicolumn{1}{c}{ High } & \multicolumn{2}{c}{ Legitimacy } \\
\cline { 3 - 4 } & \multirow{2}{*}{$\begin{array}{l}\text { Benefits }> \\
\text { costs }\end{array}$} & $\begin{array}{c}\text { Genuine } \\
\text { compliance }\end{array}$ & $\begin{array}{c}\text { Rationality-based } \\
\text { compliance }\end{array}$ \\
\cline { 3 - 4 } Rationality & $\begin{array}{l}\text { Costs }> \\
\text { benefits }\end{array}$ & $\begin{array}{c}\text { Legitimacy-based } \\
\text { compliance }\end{array}$ & Non-compliance \\
\cline { 3 - 4 } & & &
\end{tabular}

Figure 2: Explaining the compliance behaviour of EU accession states

(NOUTCHEVA [70: 29])
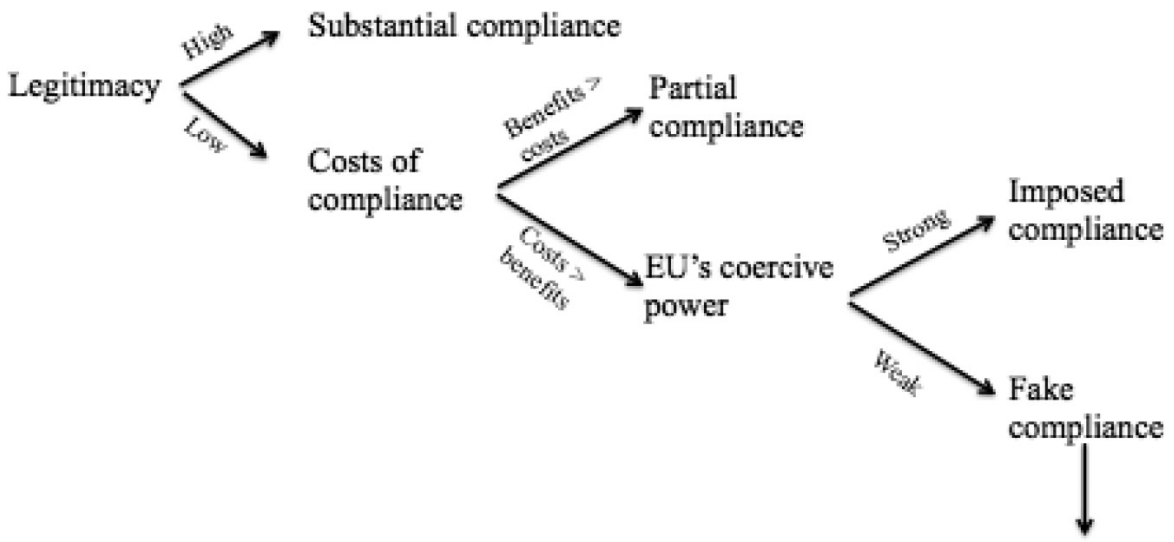

Reversed compliance

Figure 3: Legitimacy, costs of compliance, EU power and compliance outcomes

(NOUTCHEVA [70: 32]) 


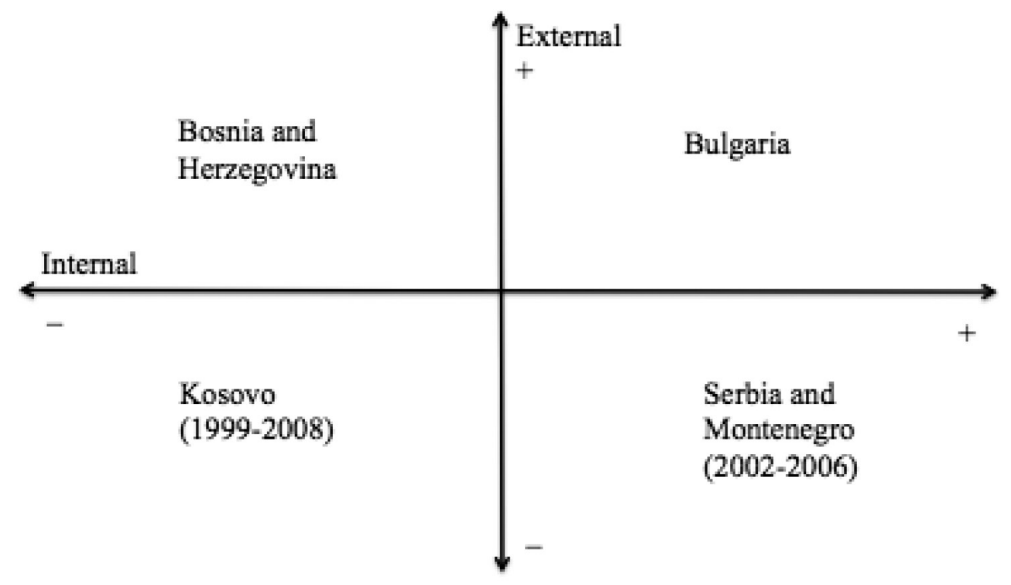

Figure 4: Sovereignty in the Balkans (NOUTCHEVA [70: 9])

Table 3: Timeline: ex-Yugoslavia and ex-Czechoslovakia in a comparative perspective (1990 - 2019; [7], [28] - [29], [33: 24] - [34: 295], [77], [81], [88] - [90], [91: 97], [92: 675-676], [93: 901], [94])

\begin{tabular}{|c|c|c|}
\hline Year & Ex-Yugoslavia & Ex-Czechoslovakia \\
\hline 1990 & XK as Republic of Kosovo & $\begin{array}{l}\text { CS Agreement between the EEC and the EURATOM } \\
\text { and the Czech and Slovak Federal Republic on Trade } \\
\text { and Commercial and Economic Cooperation }\end{array}$ \\
\hline 1991 & HR, SI \& MK declared independence & $\begin{array}{l}\text { CS Visegrad Group (V3), } \\
\text { Europe Agreement signed between the Community } \\
\text { and the Czech and Slovak Federal Republic (16 } \\
\text { December 1991) }\end{array}$ \\
\hline 1992 & $\begin{array}{l}\text { BA independence; } \\
\text { RS \& ME as new Federal Republic of } \\
\text { Yugoslavia (State Union of Serbia and } \\
\text { Montenegro) }\end{array}$ & CEFTA \\
\hline 1993 & $\begin{array}{l}\text { Copenhagen European Council: Copenhagen } \\
\text { criteria; } \\
\text { SI Cooperation Agreement signed between the } \\
\text { EEC and Slovenia }\end{array}$ & $\begin{array}{l}\text { CZ \& SK independent countries; } \\
\text { Visegrad Group (V4); } \\
\text { Copenhagen European Council: Copenhagen criteria; } \\
\text { CZ \& SK Europe Agreement }\end{array}$ \\
\hline 1994 & Essen European Council & Essen European Council \\
\hline 1995 & BA Dayton/Paris Peace Agreement & SK applied for EU \\
\hline 1996 & SI applied for EU & $\mathbf{C Z}$ applied for EU \\
\hline 1997 & $\begin{array}{l}\text { Luxembourg European Council: } \\
\text { SI bilateral intergovernmental conference to be } \\
\text { convened in } 1998\end{array}$ & $\begin{array}{l}\text { Luxembourg European Council: } \\
\text { CZ bilateral intergovernmental conference to be } \\
\text { convened in 1998; } \\
\text { SK preparation of negotiations to be speeded up in } \\
\text { particular through analytical examination of EU } \\
\text { acquis }\end{array}$ \\
\hline 1998 & SI accession negotiations launched & $\mathbf{C Z}$ accession negotiations launched \\
\hline 1999 & $\begin{array}{l}\text { SI Europe (association) Agreement; } \\
\text { XK UNSCR 1244/1999 }\end{array}$ & Helsinki European Council \\
\hline 2000 & $\begin{array}{l}\text { Feira European Council: all SAP countries } \\
\text { "potential candidates" for EU membership; } \\
\text { Zagreb Summit: SAP launched }\end{array}$ & SK accession negotiations launched \\
\hline 2001 & HR \& MK signed SAA & \\
\hline 2002 & $\begin{array}{l}\text { Copenhagen European Council: } \\
\text { SI completion of accession negotiations for } \\
2004 \text { EU enlargement }\end{array}$ & $\begin{array}{l}\text { Copenhagen European Council: } \\
\text { CZ \& SK completion of accession negotiations for } \\
2004 \text { EU enlargement }\end{array}$ \\
\hline
\end{tabular}




\begin{tabular}{|c|c|c|}
\hline 2003 & $\begin{array}{l}\text { Thessaloniki European Council: } \\
\text { EU perspective for the Western Balkans } \\
\text { reiterated (Thessaloniki Agenda); } \\
\text { HR applied for EU }\end{array}$ & \\
\hline 2004 & $\begin{array}{l}\text { SI joined the EU; } \\
\text { HR candidate country status; } \\
\text { MK SAA enters into force, applied for EU }\end{array}$ & CZ \& SK joined the EU \\
\hline 2005 & $\begin{array}{l}\text { HR SAA enters into force, accession } \\
\text { negotiations launched; } \\
\text { MK candidate country status }\end{array}$ & \\
\hline 2006 & $\begin{array}{l}\text { Renewed consensus on enlargement; } \\
\text { CEFTA 2006; } \\
\text { ME declared independence; } \\
\text { MK European Partnership }\end{array}$ & \\
\hline 2007 & $\begin{array}{l}\text { SI joined the Euro \& Schengen area; } \\
\text { ME European Partnership, signed SAA }\end{array}$ & CZ \& SK joined the Schengen area \\
\hline 2008 & $\begin{array}{l}\text { XK unilaterally declared independence, } \\
\text { EULEX; } \\
\text { RS \& BA European Partnership, signed SAA; } \\
\text { MK Accession Partnership; } \\
\text { ME applied for EU }\end{array}$ & \\
\hline 2009 & RS applied for EU & $\begin{array}{l}\text { SK joined the Euro area; } \\
\text { CZ Presidency of the Council of the European Union }\end{array}$ \\
\hline 2010 & $\begin{array}{l}\text { ME SAA enters into force, candidate country } \\
\text { status; } \\
\text { XK ICJ Opinion on the Kosovo declaration } \\
\text { of independence and UN General Assembly } \\
\text { resolution }\end{array}$ & \\
\hline 2011 & $\begin{array}{l}\text { HR completion of accession negotiations for } \\
2013 \text { EU enlargement; } \\
\text { RS - XK EU-facilitated dialogue launched }\end{array}$ & \\
\hline 2012 & $\begin{array}{l}\text { ME accession negotiations launched; } \\
\text { RS candidate country status; } \\
\text { MK High Level Accession Dialogue; } \\
\text { BA High Level Dialogue on the Accession } \\
\text { Process; } \\
\text { XK declared end of supervised independence, } \\
\text { SAA feasibility study }\end{array}$ & \\
\hline 2013 & $\begin{array}{l}\text { HR joined the EU; } \\
\text { RS - XK First agreement of principles } \\
\text { governing normalisation of relations; } \\
\text { RS SAA enters into force }\end{array}$ & \\
\hline 2014 & $\begin{array}{l}\text { "Berlin process": } \\
\text { "Western Balkans Six" initiative; } \\
\text { RS accession negotiations launched; } \\
\text { XK SAA initialled }\end{array}$ & \\
\hline 2015 & $\begin{array}{l}\text { Medium-term strategy for EU enlargement } \\
\text { policy; } \\
\text { BA SAA enters into force; } \\
\text { XK signed SAA }\end{array}$ & \\
\hline 2016 & $\begin{array}{l}\text { BA applied for EU; } \\
\text { XK SAA enters into force }\end{array}$ & SK Presidency of the Council of the European Union \\
\hline 2017 & $\begin{array}{l}\text { Following the } 2016 \text { Communication on EU } \\
\text { Enlargement Policy next Communication in } \\
2018\end{array}$ & $\begin{array}{l}\text { White Paper on the Future of Europe: Reflections and } \\
\text { scenarios for the EU27 by } 2025\end{array}$ \\
\hline
\end{tabular}




\begin{tabular}{|l|l|l|}
\hline 2018 & Western Balkans Strategy; & \\
& EU-Western Balkans summit (Sofia & \\
& Declaration and Sofia Priority Agenda); & \\
& MK European Commission repeats its \\
unconditional recommendation to open & accession negotiations (following its 2009- \\
& 2014 annual recommendations) & \\
\hline $\mathbf{2 0 1 9}$ & MK the Prespa Agreement enters into force & \\
\hline
\end{tabular}

Legend: $\quad$ BA - Bosnia and Herzegovina; CS - federation of CZ \& SK; CZ - Czech Republic/Czechia as of 18 September 2018; HR - Croatia; ME - Montenegro; MK - the former Yugoslav Republic of Macedonia (FYROM)/Republic of North Macedonia as of 15 February 2019; RS - Serbia; SAA - Stabilisation and Association Agreement; SAP - Stabilisation and Association Process; SI - Slovenia; SK - Slovakia; XK - Kosovo (UNSCR 1244/1999).

\begin{tabular}{|c|c|c|}
\hline $\begin{array}{l}\text { Non-compliance } \\
\text { or reversed } \\
\text { compliance }\end{array}$ & $\begin{array}{c}\text { Partial } \\
\text { compliance }\end{array}$ & $\begin{array}{c}\text { Substantial } \\
\text { compliance } \\
\text { (voluntary or imposed) }\end{array}$ \\
\hline
\end{tabular}

Figure 5: The compliance behaviour of Balkan accession states (NOUTCHEVA [70: 4])

\begin{tabular}{|c|c|c|c|}
\hline & \multicolumn{2}{|c|}{ Legitimacy } \\
\hline & & High & Low \\
\hline & $\begin{array}{l}\text { Benefits > } \\
\text { costs }\end{array}$ & Bulgaria & $\begin{array}{l}\text { Bosnia and } \\
\text { Herzegovina }\end{array}$ \\
\hline Rationality & $\begin{array}{l}\text { Costs }> \\
\text { benefits }\end{array}$ & & $\begin{array}{l}\text { Serbia-Montenegro } \\
\text { (2002-2006) } \\
\text { Kosovo (1999-2008) }\end{array}$ \\
\hline
\end{tabular}

Figure 6: Explaining the compliance behaviour in the Balkans (NOUTCHEVA [70: 200])

Table 4: Account of the case of Bosnia and Herzegovina by the COUNCIL OF THE EU (2014), the EUROPEAN EXTERNAL ACTION SERVICE (2014) and the EUROPEAN COMMISSION (2015)

\footnotetext{
"The Council expresses serious concern that the country [Bosnia and Herzegovina] remains at a standstill in its EU integration process ... The Council calls on Bosnia and Herzegovina to act swiftly and with determination on the Council conclusions of 15 December 2014." [95: 10])

"[T]he Council today has decided that we will be ready to re-sequence the order in which the conditionality will be faced. We have agreed with the ministers, after having agreed with the Bosnian leadership, that in Sarajevo there will be a work starting tomorrow to draft and agree on a written declaration, a written commitment, from the side of the presidency, of the leadership of different parties and a vote of the Parliament in Bosnia and Herzegovina to clearly state the commitment and the engagement of the leadership and of the population that is more than ready to move towards a European Union, to reforms, starting from economic and social reforms, but then also tackling the functionality of the State and all the different levels of the authorities. ... [T]his could be a turning point in the way of Bosnia and Herzegovina towards the European Union." [72]

"The new tripartite Presidency of Bosnia and Herzegovina initiated a written commitment to undertake reforms and advance the European integration process. The written commitment, whose language fully reflected the conclusions of the EU Foreign Affairs Council of December 2014, was signed by the leaders of all the 14 political parties represented in the Parliamentary Assembly, and endorsed by Bosnia and Herzegovina's Parliament in February [2015].” [24: 7]
} 
Table 5: Bosnia and Herzegovina, and Kosovo (UNSCR 1244/1999) in the light of EU acquis communautaire (based on [24] - [25])

\begin{tabular}{|c|c|c|c|c|}
\hline \multirow{2}{*}{ Copenhagen criteria for $\mathbf{E} \mathbf{U}$ membership } & \multicolumn{2}{|c|}{ BA 2015 Report } & \multicolumn{2}{|c|}{ XK 2015 Report } \\
\hline & State of play & Progress & State of play & Progress \\
\hline \multicolumn{5}{|l|}{ Political criteria } \\
\hline Democracy & civil society & - & civil society & $+/-$ \\
\hline Public administration reform & -- & - & - & + \\
\hline Rule of law & - & $+/-$ & -- & $+/-$ \\
\hline Human rights and the protection of minorities & $\begin{array}{l}\text { freedom of } \\
\text { expression }\end{array}$ & -- & $\begin{array}{l}\text { freedom of } \\
\text { expression }\end{array}$ & - \\
\hline Regional issues and international obligations & WB6 & TEN-T & WB6 & TEN-T \\
\hline
\end{tabular}

\section{Economic criteria}

The existence of a functioning market economy The capacity to cope with competitive pressure and market forces within the Union

\begin{tabular}{|c|c|c|c|c|}
\hline-- & $+/-$ & -- & $+/-$ \\
\hline-- & $+/-$ & -- & - \\
\hline
\end{tabular}

\section{European standards (Acquis communautaire)}

Internal market

\begin{tabular}{|l|c|c|c|c|}
\hline Free movement of goods & -- & $+/-$ & -- & $+/-$ \\
\hline $\begin{array}{l}\text { Movement of persons, services and right of } \\
\text { establishment }\end{array}$ & -- & $+/-$ & -- & $+/-$ \\
\hline Free movement of capital & $+/-$ & - & - & $+/-$ \\
\hline Customs and taxation & +- & $+/-$ & customs $+/-$ & $+/-$ \\
\cline { 3 - 5 } & & taxation -- & $+/-$ \\
\hline Competition & - & - & -- & - \\
\hline Public procurement & - & + & -- & $+/-$ \\
\hline Intellectual property law & $+/-$ & $+/-$ & - & $+/-$ \\
\hline Employment and social policies, public health policy & -- & - & -- & - \\
\hline Education and research & -- & - & -- & - \\
\hline WTO & -- & - & -- & - \\
\hline
\end{tabular}

Sectoral policies

\begin{tabular}{|l|c|c|c|c|}
\hline Industry and SMEs & -- & - & - & $+/-$ \\
\hline Agriculture and fisheries & -- & $+/-$ & - & $+/-$ \\
\hline Environment and climate change & -- & $+/$ & -- & - \\
\hline Transport policy & -- & $+/-$ & -- & $+/-$ \\
\hline Energy & -- & $+/-$ & -- & $+/-$ \\
\hline Information society and media & -- & -- & - & $+/-$ \\
\hline Financial control & -- & $+/-$ & -- & $+/-$ \\
\hline Statistics & -- & $+/-$ & $(-)-$ & + \\
\hline Justice, freedom and security & - & $+/-$ & -- & $+/-$ \\
\hline
\end{tabular}

Legend: $\quad$ BA - Bosnia and Herzegovina; TEN-T - Trans-European Transport Network; WB6 - Western Balkans Six; XK - Kosovo (UNSCR 1244/1999); assessment scale for the state of play: early stage $(--)$; some level of preparation (-); moderately prepared (+/-); good level of preparation $(+)$; well advanced $(++)$; assessment scale for progress: backsliding $(--)$; no progress $(-)$; some progress $(+/-)$; good progress $(+)$; very good progress $(++)$.

$34 \quad$ World Trade Organisation (alias WTO): Bosnia and Herzegovina not a member of WTO, but with observer status (has held negotiations for accession to the WTO); Kosovo (UNSCR 1244/1999) not a member of WTO (has taken no formal steps to join). 